\title{
INLINE BLOOD GAS ANALYSIS BY GAS CHROMATOGRAPHY IN PATIENTS DURING AND AFTER CORONARY ARTERY SURGERY
}

\author{
Emerson A. Moffitt, Richard G. Mclaren, David D. Imrie, Christopher T.B. Allen, \\ C. Edwin Kinley, and James C.W. Parrott
}

THE ABILITY to determine tensions of oxygen and carbon dioxide nearly continuously in the human blood stream has major advantages over intermittent sampling and measurement by conventional laboratory "bench" analysis. Besides having the information at all times, there is greater accuracy of the quantification by eliminating sampling errors and poor handling. The inevitable delay before bench analysis causes changes in both $\mathrm{Pa}_{\mathrm{O}_{2}}$ and $\mathrm{Pa}_{\mathrm{CO}_{2} .}{ }^{1} \mathrm{Cur}$ rently, methods for inline blood gas analysis in blood vessels or pump oxygenator lines by miniature polarographic means (electrodes) have not gained wide clinical acceptance and use, because they have not been easy to use and to keep accurate over long periods of time.

Another approach to inline blood gas analysis has been developed by Massaro and co-workers ${ }^{2}$ by use of a gas chromatograph system, the Sentorr Blood Gas Analyser (Ohio Medical Products, Inc.). Oxygen and carbon dioxide diffuse through the gas-permeable membrane of a small catheter probe in the brachial arterial blood-stream.

The probe is inserted through a percutaneous 18-gauge needle. The gases are drawn into the apparatus at the patient's side; their tensions are measured by chromatography every four minutes and printed out. No blood is withdrawn, only gases. Measurement of arterial pressure and sampling of blood as needed is done through the same needle in the brachial artery that contains the probe.

We studied the performance of the Sentorr system in eight patients having coronary artery bypass grafting, before, during and for 24 hours after perfusion, to assess its usefulness in patient care. In addition, we compared the results obtained by the Sentorr system with those obtained

Emerson A. Moffitt, M.D., Richard G. McLaren, M.B., B.S., David D. Imrie, M.B., B.S., Christopher T.B. Allen, M.B., B.S., C. Edwin Kinley, M.D., and James C.W. Parrott, M.D. Departments of Anaesthesia and Surgery, Dalhousie University and Maritime Heart Centre, Halifax, N.S.

Presented at the Canadian Anaesthetists' Society Annual Meeting in Ottawa, June 19-22, 1978.

Canad. Anaesth. Soc. J., vol. 26, no. 3, May 1979 by conventional blood gas analysis of arterial samples taken simultaneously.

\section{Patients Studied}

Seven men and one woman were included in the study, with their consent. Their ages averaged 55 years, weight $74.2 \mathrm{~kg}$ and surface area $1.81 \mathrm{~m}^{2}$. Four patients each received three and four vein grafts. Six had previous cardiac infarction and all were taking propranolol up to and through the day before operation. At preoperative cardiac catheterization, their cardiac indices averaged $3.2 \mathrm{l} / \mathrm{minute}^{\prime} \mathrm{m}^{2}$ (range $2.0-4.9$ ) and their mean ejection fraction was 0.60 (range 0.46-0.74). All patients recovered and went home after an average of 14 days postoperatively.

\section{Data On anaesthesia and Perfusion}

Thiopentone (mean $250 \mathrm{mg}$ ) and pancuronium (mean $10 \mathrm{mg}$ ) were given. Maintenance of anaesthesia was with nitrous oxide and oxygen (50:50) plus halothane or enflurane (four patients each). All patients had a Swan-Ganz catheter inserted through the right internal jugular vein for measurement of pulmonary arterial, wedge and right atrial pressures.

Whole body perfusion lasted an average of 157 minutes (range $124-227$ ) at $28-38^{\circ} \mathrm{C}$ at a flow of $2.5 \mathrm{l} / \mathrm{min} \cdot \mathrm{m}^{2}$. Duration of anaesthesia averaged 5 hours and 59 minutes.

\section{Operation of the Sentorr Blood Gas} ANALYSER

The basic components are an intra-arterial closed tip catheter and the analyser unit, which contains the columns for chromatography, control logic boards and lecture bottles for calibration (oxygen, carbon dioxide and the helium carrier gas). Operation is based on gases dissolved in blood diffusing into helium in the in-dwelling catheter, to an equilibrium concentration. Equilibration takes 3.5 minutes; then a helium flush delivers a bolus of gases from the catheter 157 
tip to the analyser for separation and measurement, which takes 30 seconds. A readout and printout hence occurs every four minutes. At equilibrium, the gas content in the lumen is independent of diffusion resistances due to protein deposition, aging, or changes in blood flow. The catheter is a gas-carrying loop in the blood stream. Helium comes from the analyser through an outer lumen and the helium and dissolved blood gases are drawn back for analysis through an inner tube. The semipermeable membrane is of dimethyl silicone rubber which is heparin coated. The outside diameter of 0.026 inch allows catheter insertion through an 18-gauge cannula. The Sentorr is calibrated daily by dialing in the barometric pressure and exposing the system to a mixture of 50 per cent oxygen and 50 per cent carbon dioxide.

\section{Protocol for Blood Gas analysis}

The sensing probe was inserted percutaneously into a brachial artery through an 18-gauge tefion needle before induction of anaesthesia. $\mathrm{Pa}_{\mathrm{H}_{2}}$ and $\mathrm{Pa}_{\mathrm{CO}_{2}}$ were then determined every four minutes by the Sentorr throughout operation and for the first 24 hours in the intensive care unit (I.C.U.). Serial samples of arterial blood were drawn and iced within two minutes for bench analysis in the clinical laboratory and corrected to the pharyngeal temperature of the patient. The average time from drawing of samples to analysis was approximately 15 minutes because the blood gas laboratory was a considerable distance from the operating rooms. The polarographic system (electrodes) used was the Corning Company Model 165. These electrodes had a major calibration every 20 samples and a minor one every four samples. The $\mathrm{PO}_{2}$ electrode was calibrated at zero and 12 per cent oxygen and has an error of two per cent up to a $\mathrm{PO}_{2}$ of $150 \mathrm{~mm} \mathrm{Hg}(19.95$ $\mathrm{kPa}$ ). For comparison of the two methods, simultaneous samples were drawn before and after perfusion $\left(\mathrm{F}_{\mathrm{O}_{2}} 0.98\right)$ and at various inspired oxygen concentrations in the I.C.U. The details of ventilation and oxygenation $\left(\mathrm{FI}_{\mathrm{O}_{2}}\right)$ at sample times were recorded.

Comparison of the determinations by the two methods were done using Student's t-test for paired data, with $\mathrm{P}<0.05$ considered significant.

\section{RESUlts}

The Sentorr system proved to be easy to operate, is essentially self-operating, highly trouble- free, and prints out data for as long as the probe remains in the blood stream. With the brachial needle kept open by our usual practice of a slow flush of heparinized fluid under pressure, clotting in the needle was not a problem. Six patients were studied through 24 hours and one for 72 hours, after operation. In one patient, clear fluid leaked into the probe six hours after operation, probably from a minute break in the membrane.

The sensor in the needle blunts the systolic peak on the arterial tracing slightly, but is not a real impediment to pressure measurement or blood sampling.

\section{Comparison To Polarographic Determinations}

\section{Arterial oxygen tension $\left(\mathrm{Pa}_{\mathrm{O}_{2}}\right)$}

During anaesthesia or in the I.C.U., with an $\mathrm{FI}_{\mathrm{O}_{2}}$ of 0.5 and body temperature above $35^{\circ} \mathrm{C}$, in 34 samples: the Sentorr $\bar{x}=111.3 \mathrm{~mm} \mathrm{Hg}(14.8$ $\mathrm{kPa}$ ) bench analysis $\bar{x}-118.4 \mathrm{~mm} \mathrm{Hg}(15.75 \mathrm{kPa})$ with S.E. of the mean $= \pm 3.7 \mathrm{~mm} \mathrm{Hg}( \pm 0.49 \mathrm{kPa})$ S.D. $=21.4 \mathrm{~mm} \mathrm{Hg}(2.85 \mathrm{kPa}) \mathrm{t}=1.83$ and $\mathrm{p}<$ 0.10 : not significant.

During anaesthesia $\left(\mathrm{F}_{\mathrm{l}_{2}}, 1.0\right)$ or whole body perfusion $\left(\mathrm{F}_{\mathrm{I}_{2}} 0.98\right)$ and body temperature above $35^{\circ} \mathrm{C}$, in 12 samples, the Sentorr $\bar{x}-302.8 \mathrm{~mm} \mathrm{Hg}$ (40.27 kPa) and bench analysis $\bar{x}=280.7 \mathrm{~mm} \mathrm{Hg}$ $(37.33 \mathrm{kPa})$, with $S . E$. of the mean $= \pm 23.9 \mathrm{~mm}$ $\mathrm{Hg}( \pm 3.18 \mathrm{kPa})$ S.D. $=82.8 \mathrm{~mm} \mathrm{Hg}(11.0 \mathrm{kPa}) \mathrm{t}=$ 0.92 and $p<0.4$ : not significant.

During whole body perfusion with an $\mathrm{Fl}_{\mathrm{O}_{2}}$ of 0.98 and a mean body temperature of $29.8^{\circ} \mathrm{C}$, in 14 samples the Sentorr $\bar{x}=341.8 \mathrm{~mm} \mathrm{Hg}(45.46$ $\mathrm{kPa})$ bench analysis $\tilde{x}=245.5 \mathrm{~mm} \mathrm{Hg}(32.65$ $\mathrm{kPa})$, with S.E. of the mean $\pm 6.2 \mathrm{~mm} \mathrm{Hg}( \pm 0.82$ $\mathrm{kPa}) \mathrm{S} . \mathrm{D} .=72 \mathrm{~mm} \mathrm{Hg}(9.58 \mathrm{kPa}) \mathrm{t}=15.5$ and $\mathrm{p}<$ 0.001 : very highly significant.

\section{Arterial carbon dioxide tension ( $\left.\mathrm{Pa}_{\mathrm{CO}_{2}}\right)$}

During anaesthesia or in the I.C.U., with body temperature above $35^{\circ} \mathrm{C}$ and ventilator setting calculated to give normocarbia, in 34 samples, the Sentorr $\bar{x}-41.1 \mathrm{~mm} \mathrm{Hg}(5.47 \mathrm{kPa})$ and bench analysis $\bar{x}=38.7 \mathrm{~mm} \mathrm{Hg}(5.15 \mathrm{kPa})$ with S.E. of the mean $= \pm 0.5 \mathrm{~mm} \mathrm{Hg}( \pm 0.07 \mathrm{kPa})$ S.E. $=2.8$ $\mathrm{mm} \mathrm{Hg}(0.37 \mathrm{kPa}) \mathrm{t}=5.6$ and $\mathrm{p}<0.001$ : very highly significant.

During whole body perfusion with a mean body temperature of $29.8^{\circ} \mathrm{C}$ and two per cent carbon dioxide added to the oxygenator, in 14 samples, the Sentorr $\bar{x}=29.5 \mathrm{~mm} \mathrm{Hg}(3.92 \mathrm{kPa})$ and bench analysis $\tilde{x} 29.7 \mathrm{~mm} \mathrm{Hg}(3.95 \mathrm{kPa})$ with S.E. of the 


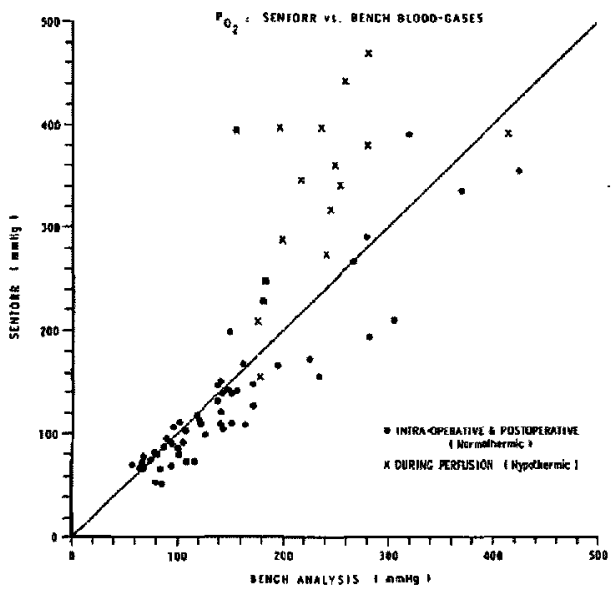

FIGURe 1 During. and after operalion with $\mathrm{Pa}_{\mathrm{O}_{2}}$ below $200 \mathrm{~mm} \mathrm{Hg} \mathrm{(26.6} \mathrm{kPa),} \mathrm{the} \mathrm{two} \mathrm{systems} \mathrm{were}$ close to each other. At high $\mathrm{Pa}_{\mathrm{O}_{2}}$ (during hypothermia) the Sentorr-system consistently read higher than the bench oxygen electrode.

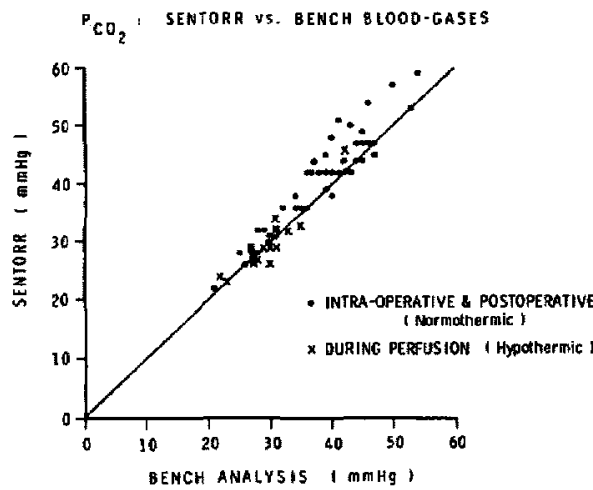

FIGURE 2 During normothermia and hypothermia there was close correlation between the Sentor and $\mathrm{PCO}_{2}$ electrode.

mean $= \pm 0.5 \mathrm{~mm} \mathrm{Hg}( \pm 0.07 \mathrm{kPa})$ S.D. $=21 \mathrm{~mm}$ $\mathrm{Hg}(2.79 \mathrm{kPa}) \mathrm{t}=0.6$ and $\mathrm{p}<0.5$ : not significant.

Graphic representation of the comparisons of analyses by the Sentorr system and by the conventional blood gas electrodes are shown in Figure 1 for oxygen and Figure 2 for carbon dioxide.

\section{Effects of Specific Events ON $\mathrm{Pa}_{\mathrm{O}_{2}}$ AND $\mathrm{Pa}_{\mathrm{CO}_{2}}$}

\section{On pump-off pump (Table I)}

An acute rise in $\mathrm{Pa}_{\mathrm{O}_{2}}$ occurs on initiating perfusion and falls on discontinuing perfusion. $\mathrm{Pa}_{\mathrm{CO}_{2}}$ decreases on beginning perfusion, with body cooling and is in normal range both before and after ending perfusion.

\section{Change in blood pressure (Table II)}

A decrease in $\mathrm{Pa}_{02}$ as arterial pressure and cardiac output fall just before perfusion is typical and is seen regularly.

III. Change in inspired oxygen $\left(\mathrm{FI}_{\mathrm{O}_{2}}\right)$ (Table III)

$A$ rise in $\mathrm{Pa}_{\mathrm{O}_{2}}$ is evident, on the next fourminute reading, after the $\mathrm{Fl}_{\mathrm{O}_{2}}$ was raised from 0.4 to 0.6 by a $T$-piece and spontaneous breathing.

\section{Effects of acule tamponade and circulatory arrest (Table IV)}

Sudden massive haemorrhage from the aorta with circulatory arrest occurred in the I.C.U. With near cessation of the circulation, the Sentorr read: $\mathrm{Pa}_{\mathrm{O}_{2}}=8 \mathrm{~mm} \mathrm{Hg}(1.06 \mathrm{kPa})$ and $\mathrm{PakO}_{2}=$ $22 \mathrm{~mm} \mathrm{Hg}(2.93 \mathrm{kPa})$. Upon relief of the tamponade and resumption of adequate circulation, the next four-minute reading showed that the tensions had returned to $114 \mathrm{~mm} \mathrm{Hg}(15.16 \mathrm{kPa})$ and $42 \mathrm{~mm} \mathrm{Hg}(5.59 \mathrm{kPa})$.

\section{Effects of suctioning and extubation}

(Table V)

Severe reduction in $\mathrm{Pa}_{\mathrm{O}_{2}}$, on the next reading after tracheal suctioning is a characteristic finding. Extubation of the trachea is also followed by a lowered $\mathrm{Pa}_{\mathrm{O}_{2}}$ unless done "on oxygen".

\section{Discussion}

In certain situations it is highly desirable to have accurate knowledge of oxygen and carbon dioxide tensions available nearly continuously at the patient's side. These situations include cardiac and neurosurgical operations, and patients in intensive care units. This now appears to be a practical possibility with the Sentorr blood gas analyser.

Expertise in inserting the sensing probe through a percutaneously placed 18-gauge needle in the brachial artery can be as easily acquired as for radial puncture. Percutaneous puncture of the brachial artery, which is considerably larger than the radial, by a teflon 18 -gauge needle has a small but acceptable risk. The needle occupies only a small portion of that artery's lumen. Brachial needles for Sentorr probe insertion have now been safely used in hundreds of patients in multiple centres. For many years before the radial artery became the site of choice, the brachial 
TABLE I

ON PUMP-OFF PUMP

\begin{tabular}{|c|c|c|c|c|}
\hline \multicolumn{2}{|c|}{$\mathrm{Pa}_{\mathrm{Ca}_{2}}$} & \multicolumn{2}{|c|}{$\mathrm{Pa}_{2}$} & \multirow[b]{2}{*}{ Details } \\
\hline kPa & $\mathrm{mm} \mathrm{Hg}$ & $\mathrm{kPa}$ & $\mathrm{mm} \mathrm{Hg}$ & \\
\hline $\begin{array}{l}4.39 \\
4.26 \\
3.33 \\
3.72\end{array}$ & $\begin{array}{l}33^{\star} \\
32 \\
25 \\
28\end{array}$ & $\begin{array}{l}15.83 \\
15.30 \\
42.83 \\
56.53\end{array}$ & $\begin{array}{l}119^{*} \\
115 \\
322 \\
425\end{array}$ & $\begin{array}{l}\mathrm{FI}_{\mathrm{O}_{2}} \text { 0.5, B.P. } 105 / 65 \\
\text { Pump on } \\
\text { FIo } 0.98, \text { B.P. } 75 \\
\text { Temp. } 32^{\circ} \mathrm{C}\end{array}$ \\
\hline $\begin{array}{l}4.66 \\
5.05 \\
5.99 \\
5.85\end{array}$ & $\begin{array}{l}35 \\
38 \\
45 \\
44\end{array}$ & $\begin{array}{l}53.60 \\
46.95 \\
20.35 \\
15.83\end{array}$ & $\begin{array}{l}403 \\
353 \\
153 \\
119\end{array}$ & $\begin{array}{l}\mathrm{FI}_{\mathrm{I}_{2}} 0.98, \text { Temp. } 36^{\circ} \mathrm{C} \\
\text { Pump off } \\
\mathrm{FI}_{\mathrm{I}_{2}} 0.5, \text { B.P. } 130 / 65\end{array}$ \\
\hline
\end{tabular}

* Reading every four minutes.

TABLE II

Cifange In Blood Pressure

\begin{tabular}{|c|c|c|c|c|}
\hline \multicolumn{2}{|c|}{$\mathrm{PaCO}_{2}$} & \multicolumn{2}{|c|}{$\mathrm{PaO}_{2}$} & \multirow[b]{2}{*}{ Details } \\
\hline $\mathbf{k} \mathbf{P a}$ & $\mathbf{m m} \mathbf{H g}$ & $\mathbf{k P a}$ & $\mathrm{mm} \mathrm{Hg}$ & \\
\hline $\begin{array}{l}3.86 \\
3.86 \\
4.26 \\
3.99 \\
3.86 \\
4.12\end{array}$ & $\begin{array}{l}29 \\
29 \\
32 \\
30 \\
29 \\
31\end{array}$ & $\begin{array}{l}19.82 \\
19.82 \\
17.16 \\
12.10 \\
13.03 \\
28.33\end{array}$ & $\begin{array}{r}149 \\
149 \\
129 \\
91 \\
98 \\
213\end{array}$ & $\begin{array}{l}\mathrm{Fl}_{\mathrm{O}_{2}} \text { 0.5, B.P. 125/76 } \\
\text { Arterial Cannulation } \\
\text { Venous B.P. 105/68 } \\
\text { Cannulation B.P. 88/45 } \\
\text { Pump on } \mathrm{FI}_{\mathrm{O}_{2}} 0.98\end{array}$ \\
\hline
\end{tabular}

TABLE III

Change In $\mathrm{Fi}_{\mathrm{O}_{2}}$

\begin{tabular}{|c|c|c|c|c|}
\hline \multicolumn{2}{|c|}{$\mathrm{PaCO}_{z}$} & \multicolumn{2}{|c|}{$\mathrm{PaO}_{2}$} & \multirow[b]{2}{*}{ Details } \\
\hline $\mathbf{k P a}$ & $\mathrm{mm} \mathrm{Hg}$ & $\mathbf{k P a}$ & $\mathbf{m m} \mathbf{H g}$ & \\
\hline $\begin{array}{l}6.78 \\
7.05 \\
7.32 \\
7.32\end{array}$ & $\begin{array}{l}51 \\
53 \\
55 \\
55\end{array}$ & $\begin{array}{l}14.36 \\
15.03 \\
21.41 \\
24.07\end{array}$ & $\begin{array}{l}108 \\
113 \\
161 \\
181\end{array}$ & $\begin{array}{l}\text { T-piece, } \mathrm{FI}_{\mathrm{O}_{2}} 0.4 \\
\mathrm{Fr}_{\mathrm{O}_{2}} \text { to } 0.6 \\
\text { T-piece } \\
\text { Same }\end{array}$ \\
\hline
\end{tabular}

artery was regularly used by open-heart surgical teams for pressure measurement in thousands of patients. The only blood flow problems distal to brachial needles that we have tracked down, have been in infants or patients in the low cardiac output state. Peripheral flow inadequacy was part of poor general circulation.

One disadvantage is that the elbow must be prevented from bending to avoid needle dislodgement or kinking of the delicate probe. It would be ideal to insert the probe through an 18-gauge needle in a radial artery but blood flow past a radial needle is not sufficient for accurate gas measurement.2 A longer probe inserted through the radial site may be the answer.
Measurement of gas tensions

The dissolved gases in arterial blood cross the probe's membrane and equilibriate in the helium carrier gas contained in the probe lumen, over a 3.5-minute period. Then the helium-oxygencarbon dioxide mixture is rapidly flushed into the analyser by helium, and tensions are determined by chromatography in the next $\mathbf{3 0}$ seconds. So a sample drawn for analysis by polarographic electrodes in the fourth minute of Sentorr sampling should provide the best comparison. This in fact was the procedure used and the only time lag was after icing, in transport to the electrodes. Oxygen: The Sentorr system has been found to be highly accurate when compared with known 
TABLE IV

Acute Tamponade IN I.C.U.

\begin{tabular}{|c|c|c|c|c|c|}
\hline \multirow[b]{2}{*}{ Time } & \multicolumn{2}{|c|}{$\mathrm{PaCO}_{2}$} & \multicolumn{2}{|c|}{$\mathrm{PaO}_{2}$} & \multirow[b]{2}{*}{ Details } \\
\hline & $\mathbf{k P a}$ & $\mathrm{mm} \mathbf{H g}$ & $\mathbf{k P a}$ & $\mathrm{mm} \mathrm{Hg}$ & \\
\hline 1425 & $\begin{array}{l}4.12 \\
5.72\end{array}$ & $\begin{array}{l}31 \\
43\end{array}$ & $\begin{array}{l}13.97 \\
14.36\end{array}$ & $\begin{array}{l}105 \\
108\end{array}$ & $\begin{array}{l}\text { To C-V I.C.U, } \\
\text { On ventilator } \mathrm{F}_{\mathrm{Io}_{2}} 0.5\end{array}$ \\
\hline 1645 & $\begin{array}{l}5.19 \\
3.19\end{array}$ & $\begin{array}{l}39 \\
24\end{array}$ & $\begin{array}{l}14.23 \\
17.16\end{array}$ & $\begin{array}{l}107 \\
129\end{array}$ & $\begin{array}{l}\text { Steady chest drainage } \\
\text { Acute tamponade }\end{array}$ \\
\hline 1653 & $\begin{array}{l}2.79 \\
2.93\end{array}$ & $\begin{array}{l}21 \\
22\end{array}$ & $\begin{array}{r}15.56 \\
1.06\end{array}$ & $\begin{array}{r}117 \\
8\end{array}$ & $\begin{array}{l}\text { B.P. } 30 / 20 \\
\mathrm{FlO}_{2} 1.0\end{array}$ \\
\hline 1701 & $\begin{array}{l}3.19 \\
5.59\end{array}$ & $\begin{array}{l}24 \\
42\end{array}$ & $\begin{array}{r}0.67 \\
15.16\end{array}$ & $\begin{array}{r}5 \\
114\end{array}$ & $\begin{array}{l}\text { Chest opened } \\
\text { B.P. } 80 / 30\end{array}$ \\
\hline 1709 & $\begin{array}{l}7.85 \\
5.59\end{array}$ & $\begin{array}{l}59 \\
42\end{array}$ & $\begin{array}{l}21.01 \\
35.25\end{array}$ & $\begin{array}{l}158 \\
265\end{array}$ & $\begin{array}{l}\text { blood, dopamine } \\
\text { Still } \mathrm{F}_{\mathrm{I}_{2}} 1.0\end{array}$ \\
\hline 1717 & 4.39 & 33 & 40.83 & 307 & Return to O.R. \\
\hline
\end{tabular}

TABLE V

EFfact of SUCtIoning, Extubation

\begin{tabular}{|c|c|c|c|c|}
\hline \multicolumn{2}{|c|}{$\mathrm{PaCO}_{2}$} & \multicolumn{2}{|c|}{$\mathbf{P a}_{\mathrm{O}_{2}}$} & \multirow[b]{2}{*}{ Details } \\
\hline $\mathrm{kPa}$ & $\mathrm{mm} \mathrm{Hg}$ & $\mathbf{k P a}$ & $\mathrm{mm} \mathbf{H g}$ & \\
\hline $\begin{array}{l}6.78 \\
7.05\end{array}$ & $\begin{array}{l}51 \\
53\end{array}$ & $\begin{array}{l}10.77 \\
10.77\end{array}$ & $\begin{array}{l}81 \\
81\end{array}$ & $\mathrm{FI}_{\mathrm{O}_{2}} 0.4 \mathrm{~T}$-piece \\
\hline $\begin{array}{l}4.12 \\
6.38 \\
6.38\end{array}$ & $\begin{array}{l}31 \\
48 \\
48\end{array}$ & $\begin{array}{r}3.86 \\
10.91 \\
11.31\end{array}$ & $\begin{array}{l}29 \\
82 \\
85\end{array}$ & $\begin{array}{l}\mathrm{FI}_{\mathrm{I}_{2}} 0.4 \mathrm{~T} \text {-piece } \\
\text { Extubated }\end{array}$ \\
\hline $\begin{array}{l}5.99 \\
5.85 \\
6.38\end{array}$ & $\begin{array}{l}45 \\
44 \\
48\end{array}$ & $\begin{array}{r}8.78 \\
9.71 \\
11.31\end{array}$ & $\begin{array}{l}66 \\
73 \\
78\end{array}$ & $\begin{array}{l}\text { On air } \\
40 \% \mathrm{O}_{2} \text { by mask } \\
40 \% \mathrm{O}_{2} \text { by mask }\end{array}$ \\
\hline
\end{tabular}

oxygen tensions by tonometry, both in vitro $^{2}$ and in animals. ${ }^{3}$

In our study, in patients at body temperatures above $35^{\circ} \mathrm{C}$, there was no statistically significant difference in $\mathrm{Pa}_{\mathrm{O}_{2}}$ determined by the indwelling Sentorr probe and the conventional polarographic electrode. This was true with the patients breathing 50 per cent or 100 per cent oxygen or during whole body perfusion with 98 per cent entering the oxygenator. That bench analysis averaged $22 \mathrm{~mm} \mathrm{Hg} \mathrm{(2.93} \mathrm{kPa}$ ) less than the Sentorr $(303 \mathrm{~mm} \mathrm{Hg}$ vs. $281 \mathrm{~mm} \mathrm{Hg}$ ) (40.3 kPa vs. 37.37 $\mathrm{kPa}$ ) at the high $\mathrm{FI}_{\mathrm{O}_{2}}$ is likely due to the initial loss of oxygen inherent in drawing a blood sample."

Since our arterial blood samples were iced quickly and measured within 15 minutes, with only a small change in $\mathrm{PO}_{2}$ with passage of time, ${ }_{4}{ }^{1-3}$ we did no temperature correction for elapsed time.
During whole body perfusion, our patients were cooled to a mean temperature of $29.8^{\circ} \mathrm{C}$ and the perfusate had 98 per cent oxygen bubbled through it. Under these conditions, the inline probe read very significantly higher than the conventional electrodes in the laboratory $(\bar{x}=342$ $\mathrm{mm} \mathrm{Hg}$ (45.49 kPa) Sentorr vs. $\bar{x}-241 \mathrm{~mm} \mathrm{Hg}$ (32.05 $\mathrm{kPa}$ ) bench). There are several possible reasons for this. Most blood gas electrodes, including ours, are not calibrated routinely at high oxygen tensions. ${ }^{5}$ Since we were comparing the bench blood gas results as we normally receive them in the operating room to the Sentorr, we did not calibrate at a high $\mathrm{PO}_{2}$. To test the absolute accuracy of both systems at high $\mathrm{F}_{\mathrm{O}_{2}}$. one certainly must calibrate both at high $\mathrm{PO}_{2}$. Our electrode has about a 7 per cent error at 80 per cent oxygen. Against this being a major factor is the finding that, at high tensions in normothermic 
blood, the bench electrode was not significantly different from the Sentorr, which has known accuracy at high tensions. ${ }^{2.3}$

The temperature of the blood sample is more likely to have an influence. The Sentorr system does its measurement at the temperature of the patient's blood. The electrode determination is corrected to the pharyngeal temperature of the patient. During the initial period of cooling and for a considerable period during hypothermic perfusion, the circulating blood is at a lower temperature than the pharyngeal tissue. Since the correction (an increase in $\mathrm{mm} \mathrm{Hg}$ ) is inversely related to the temperature used, the bench correction gives a lower $\mathrm{Pa}_{\mathrm{O}_{2}}$ than the Sentorr, which is corrected to a lower temperature. Although the Sentorr's function is to correct temperature to that of the patient's blood, we did not confirm that in each study. As previously noted, this disparity between the two methods of analysis disappeared upon rewarming the blood (patient), so that for most of the time during an open-heart operation, the correlation was close.

Carbon Dioxide: At temperatures above $35^{\circ} \mathrm{C}$ and normocarbia the Sentorr and bench analyses had a $2.4 \mathrm{~mm} \mathrm{Hg}(0.32 \mathrm{kPa})$ mean difference in $\mathrm{PaCO}_{2}$. Statistically this was very highly significant, but is of no clinical relevance.

At an average temperature of $29.8^{\circ} \mathrm{C}$, during perfusion and with two per cent carbon dioxide added to the perfusate, there was no significant difference between the chromatographic and polarographic systems. The inline probe accurately determines and prints out the $\mathrm{Pa}_{\mathrm{CO}_{2}}$ every four minutes. Changes of tidal volume, rate and minute ventilation are followed by an appropriately different reading four minutes later.

\section{Effects of various events on blood gases}

Tables I through $\mathrm{V}$ are evidence of the sensitivity of the Sentorr system in depicting the immediate effect on blood gases of surgical and anaesthetic events.

Initiation of whole body perfusion produces a rise in $\mathrm{Pa}_{\mathrm{O}_{2}}$ and a fall in $\mathrm{Pa}_{\mathrm{CO}_{2}}$, even when the prepump $\mathrm{Fi}_{\mathrm{O}_{2}}$ is 1.0 (Table I). Similarly, returning the oxygenating function to the patient's lungs soon results in a decrease of $\mathrm{Pa}_{\mathrm{O}_{2}}$ (at an $\mathrm{FI}_{\mathrm{O}_{2}}$ of $1,0)$ due to the inevitable shunting in the lungs.

A sudden severe, or slow steady fall in arterial pressure for any reason decreases $\mathrm{Pa}_{\mathrm{O}_{2}}$, at the same $\mathrm{FI}_{\mathrm{O}_{2}}$ and ventilation. Table II shows this effect due to decreased cardiac output just before perfusion. Table IV dramatically follows the changes as sudden profound circulatory arrest occurred from acute tamponade. The rapid return of oxygen level upon opening the chest in the I.C.U. was equally gratifying. That patient went home after the usual length of postoperative convalescence.

Changes in $\mathrm{Fl}_{\mathrm{O}_{2}}$ are effectively displayed on the next readout (Table III). Making changes in the ventilatory pattern of patients is facilitated when the effect on $\mathrm{Pa}_{\mathrm{CO}}$ is seen on the next readout from the Sentorr.

Another benefit of having the Sentorr on patients in the I.C.U. is to improve patient care. One instance of this is seen in Table $V$. Anyone seeing what vigorous and overlong suctioning does to $\mathrm{Pa}_{\mathrm{O}_{2}}$ is likely to be more expeditious and careful henceforth. The Sentorr reads a sample taken at the end of the three-and-one-half-minute gas-diffusing period. Evert so, one minute of suctioning the trachea and bronchi is regularly followed by a low $\mathrm{Pa}_{\mathrm{O}_{2}}$ reading.

\section{Clotting on the in-dwelling probe}

In their dog studies, Massaro, et al. ${ }^{2}$ found that clotting around the in-dwelling probe was a problem. We saw no evidence of that in man. The arterial needle was on a slow flush under pressure, with intermittent manual rapid flushing. If this pressure flushing system malfunctioned, the needle clotted around the sensing probe, arterial pressure and blood sampling were not possible, but the sensor probe in the bloodstream kept on functioning. We saw no evidence of clot forming on the heparin impregnated probe, either from a gradual fall in oxygen relative to bench $\mathrm{Pa}_{\mathrm{O}_{2}}$ or on removing the probe carefully through the needle. The only real cause of the probe becoming inoperative was for the patient to bend the elbow acutely just once. Kinking the probe was disastrous.

\section{SUMmarY}

A system was evaluated of measuring $\mathrm{Pa}_{\mathbf{0}_{2}}$ and $\mathrm{PaCO}_{2}$ by an inline sensor in the brachial artery and gas chromatography. Eight patients having coronary artery vein grafts were studied during anaesthesia, operation, perfusion and for 24 hours afterward.

Compared to conventional blood gas analysis by polarography (electrodes), the chromatographic method gave readings for $\mathrm{Pa}_{\mathrm{O}_{2}}$ which were not significantly different during normothermia. During hypothermic perfusion, the chromatographic system read significantly higher than the bench electrode, due at least in part to 
a difference in temperature correction. For $\mathrm{Pa}_{\mathrm{CO}}$ the correlation between the two methods was close and differences were clinically insignificant. The Sentorr blood-gas analyser provides a sensitive, accurate indicator of changes in oxygenation, ventilation and circulation during anaesthesia and in the intensive care unit.

\section{RÉSUMÉ}

Les auteurs évaluent la chromatographie gazeuse utilisée comme méthode de mesure presque continuelle des tensions artérielles en oxygène et en gaz carbonique. Les gaz sont aspirés à travers la membrane semi-perméable d'une sonde introduite dans l'artère brachiale à l'aide d'une canule de calibre 18. La $\mathrm{Pa}_{\mathrm{O}_{2}}$ et la $\mathrm{Pa}_{\mathrm{CO}_{2}}$ sont mesurées au chever du malade à toutes les quatre minutes et comparés aux résultats obtenus par les électrodes traditionnelles.

L'étude a porté sur huit malades opérés pour pontage aortocoronarien depuis l'anesthésie et pendant les 24 heures suivantes. Pour la $\mathrm{Pa}_{0}$, on n'a pas trouvé de différence statistique significative entre les méthodes chromatographique et polarographique chez les malades normothermiques lorsque la $\mathrm{FI}_{\mathrm{O}_{2}}$ se situait entre 0.5 et 1 . Pendant la perfusion hypothermique $\left(\mathrm{Fl}_{\mathrm{O}_{2}}, 0.98\right)$, les électrodes polarographiques donnaient des lectures plus basses de façon significative comparativement au système chromatographique d'analyse continue. Pour la $\mathrm{Pa}_{\mathrm{CO}_{2}}$, la corrélation a été étroite pour les deux techniques que ce soit sous hypothermie ou normothermie et la légère différence constatée n'avait pas d'implication clinique.

Plusicurs des évènements qui surviennent pendant l'anesthésie, la perfusion et la rêanima- tion ont des retentissements sur les gaz sanguins et s'enregistrent sur l'imprimante.

Chez les grands malades, l'analyse quasicontinuelle de la $\mathrm{Pa}_{\mathrm{O}_{2}}$ et de la $\mathrm{Pa}_{\mathrm{CO}_{2}}$ fournit des renseignements très précis sur l'ćtat de loxygénation, de la ventilation et de la circulation. L'usage de l'analyseur de gaz sanguins Sentorr est présenté comme une addition précieuse dans le domaine des soins aux malades cardiaques et autres grands malades.

\section{ACKNOWLEDGEMENT}

The authors thank Dr. Anne Pollett and Mr. Michael Breen for their valuable assistance.

\section{REFERENCES}

1. Fletcher, G. \& Barber, J.L. Effecl of sampling technique on the determination of $\mathrm{Pa}_{0,}$ during oxygen breathing. J. Appl. Physiol. 2l: 463 (1966).

2. Massaro, T.A., Behrens-Tepper, J., \& Updike, S.J. Non-polarographic blood gas analysis. 1. In vitro evaluation of gas chromatograph system. Biomet. Med. Dev., Arl. Org. 4 (3 \& 4), 385 (1976).

3. Behrens-Tepper, J., Massaro, T.A., Updike, S.J., \& FoL.Ts, J.D. Non-polarographic blood gas analysis. II. In vivo evaluation of gas chromatograph system. Biomat. Med. Dev., Art. Org. 5 (3) (1977)

4. KELman, G.R. \& NUNN, J.F. Nomograms for correction of blood $\mathrm{PO}_{2}, \mathrm{PCO}_{2}, \mathrm{pH}$ and base excess for time and temperature. J. Appl. Physiol. 2l: 1484 (1966).

5. Andersen, P.K., Brinklgy, M.M., Stokke, D.B., Hole, P., \& Rosendal, T. Inaccuracy of oxygen electrodes at high blood oxygen tensions. Anesthesiology 49:61 (1978).

6. Eldridge, F. \& Fretwell, L.K. Changes in oxygen tension of shed blood at various temperatures. J. Appl. Physiol. 20(4), 790 (1965). 